\title{
Educational material on genetics for schools: 'The Science behind the Jeans for Genes Day'
}

\author{
M Pembrey and J Tizzard
}

Progress E ducational Trust: L ondon, 1989

\begin{abstract}
'E ducation about the principles of heredity and the possibilities for diagnosis and prevention of congenital disorders should be promoted in primary and secondary schools.' This is a quotation from a report of an expert committee of the $\mathrm{D}$ utch $\mathrm{N}$ ational $\mathrm{H}$ ealth Council dated 1989. Numerous similar statements acknowledge the importance of genetic information in school education. The E uropean A lliance of G enetic Support groups (EAGS) in a declaration issued in Copenhagen in 1993 mentioned the education of individuals and young people in genetics and genetic disorders as one of the top priorities.

$G$ enetic issues are in the news almost every day. N ew genes, new options for diagnosis and therapies, sensational utopic predictions as well as horror scenarios are presented in the media giving rise to exaggerated hopes and unfounded fears. Y oung people are confronted with these publications. They also notice genetic traits in their families. They hear terms like 'it runs in the blood' or 'like father, like son'. They have questions.

With support of the European Union the Dutch A lliance of $G$ enetic Support groups initiated in $M$ ay 1993 a multi-national project on school education in genetics. A team of experts from various European countries got together and investigated the need for new materials and formulated requirements for their production. This led to a 'blueprint for teaching human genetics to high school and secondary modern school students' (Commission of the European Communities DG XII-F-6 SDME 2/38, no. GENO-CT91-0040 EASE). Several teaching packs have been produced since.
\end{abstract}

In the U K the G enetic Interest G roup together with the Wellcome Trust recently produced a comprehensive $G$ enes and you pack (cross-curricular materials for key stage 4, 14-16 years). In Belgium the Centre for Genetic Services in Leuven produced a video for secondary schools and organised an impressive exhibition with an accompanying book: Het ABC van het DNA. In the Netherlands the above-mentioned A lliance developed several teaching packs and a special, award-winning video to illustrate chances and choices, focused on decision making.

In O ctober 1997 the Progress E ducational Trust in London produced a teaching pack in connection with the annual J eans for $G$ enes $D$ ay in the $U$ nited $K$ ingdom. On Friday $10 \mathrm{O}$ ctober the population of the UK was encouraged to wear jeans and donate a pound for research into the understanding of genes and development of potential future treatments such as gene therapy. In 1996 almost a million pounds were raised by the campaign. Jeans for $G$ enes $D$ ay is organised by G reat O rmond Street H ospital Children's Charity and three other specialist charities.

Schools are specially invited to participate in the campaign. The teaching pack The Science behind the Jeans for $G$ enes $D$ ay serves to provide genetic background material for the pupils. Some elements of the pack can also be used for personal and social educational sessions. The pack is available in two versions; one for primary level (age group 5-11 years) and one for secondary level (age group 11-16 years) school education. It consists of the brochure The Progress G uide to $\mathrm{G}$ enetics, case studies, worksheets, teachers' notes and a questionnaire for evaluation.

The Progress G uide to G enetics (M Pembrey, 1996) is a simple, illustrated, stand-alone guide on 'how genes work and sometimes go wrong'. It is an adequate information resource for the teacher.

The teachers' notes give an outline of the educational aims including links to the national curriculum, and ideas for classroom activities. The worksheets focus on some of the key areas of genetics and are intended to help pupils express their own opinions. The case studies, 
while rather medically oriented, give a human face to genetics and will increase understanding of genetic disorders.

The bottom line of each page of the teaching pack reminds the reader of the appeal by the $\mathrm{G}$ reat $\mathrm{O}$ rmond Street Charity. O ne would perhaps prefer a combination of genetics and responsibility or solidarity rather than a combination of genetics and charity.

The names of the editors of the package, $M$ arcus Pembrey and Juliet Tizzard guarantee high expertise, experience and commitment. Professor Pembrey's field of expertise covers research, teaching and genetic counselling. As Mothercare Professor of Paediatric $G$ enetics he knows the potential benefits of genetic knowledge for families and the need and requirements of timely, reliable and comprehensive information tailored to the various relevant target groups. The presentation is attractive and will appeal to pupils. The module system will be appreciated by teachers.

There are, however, also some points of criticism. The information presented requires far more than a 30-minute session as the teachers' notes suggest. Class discussions will raise questions related to family problems which deserve proper attention. The teachers' notes advise refraining from asking pupils to draw their family tree because this can have unexpected repercussions. At the same time worksheet B for primary schools presents keys for drawing family trees. To believe that pupils will not think about their own family while studying pedigrees is probably an underestimation of the intelligence of pupils.
The lessons intended for primary schools appear rather difficult. A simple approach would probably have more effect.

The questionnaire for teachers will certainly contribute to new revised editions which might be a little less cognitive and rather more social and attitude oriented.

Finally, as a whole the package is well considered, well written and functionally illustrated. It is an excellent approach for better understanding by pupils of the complex genetic knowledge with which they are confronted in the media and many of them also in their family. Moreover, it will make clear that genetics is an issue in which every human being has an involvement.

Y sbrand Poortman

Teacher of Biology

Vice President, European A lliance of G enetic Support Groups (EAGS)

The teaching pack The Science behind Jeans for $G$ enes $D$ ay, including the brochure The P rogress $G$ uide to $\mathrm{G}$ enetics can be obtained from:

Progress Educational Trust, 16 Mortimer Street, London W 1N 7RD. Tel: +44(0)171 636 5390; E-mail: jtizzard@progress.org.uk

$G$ enes and you is available from:

Genetic Interest Group, Farringdon Point, 29-35 Farringdon Road, London E C1M 3J B. Tel. +44(0)171 4300090; Fax: +44(0)171 4300092; E-mail: 101366.760@compuserve.com. 